\title{
DOES ERYSIMUM HUNGARICUM ZAPAL. (BRASSICACEAE) STILL GROW IN ROMANIA?
}

\author{
Peter TURIS ${ }^{1}$, Ingrid TURISOVA ${ }^{2}$ \\ ${ }^{1}$ The Low Tatras National Park Administration, Lazovná 10, SK-974 04 Banská Bystrica, Slovakia \\ ${ }^{2}$ Matej Bel University in Banska Bystrica, Faculty of Natural Sciences, Tajovského 40, \\ SK-974 01 Banská Bystrica, Slovakia \\ e-mail: peter.turis@sopsr.sk
}

\begin{abstract}
The Carpathian stenoendemic species Erysimum hungaricum Zapał. (Brassicaceae) had not been observed at its only known locality in the Maramureş Mts in Romania for more than 80 years. Research from June 2018 has confirmed its presence on the southern slope of Mt. Lostun Mic $(1595 \mathrm{~m})$. Compared to the past, the number of micro-locations was reduced to a single one of approximately $200 \mathrm{~m}^{2}$. In the remaining population, approximately 100 flowering individuals, we made a phytocoenological relevé and determined the chemical properties of the soil $\left(\mathrm{pH}_{\mathrm{H} 2 \mathrm{O}}=6.46 ; \mathrm{pH}_{\mathrm{KCl}}=6.2\right.$; carbonate content $=8.0 \mathrm{~g} \cdot \mathrm{kg}^{-1}$; nitrogen content $=10.99 \mathrm{~g}^{-\mathrm{kg}^{-1}}$; phosphorus content $\left.=19.57 \mathrm{mg} \cdot \mathrm{kg}^{-1}\right)$. In the plant community, succession occurs from the original Festucetum saxatilis Domin 1933 to a tall-herb vegetation of the order Adenostyletalia alliariae Br.-Bl. 1931 and a growth of Picea abies. The presence of the species in different vegetation units and the comparison of older and actual soil characteristics point to its wider tolerance of the characteristics of the site. Thus, the causes of the extraordinary rarity of the species are not yet clear. Based on the IUCN sozological evaluation, the species was categorised as Critically Endangered (CR) according to criteria B2ab(ii,iv).
\end{abstract}

Keywords: wallflower, taxonomy, distribution, population characteristic, Adenostyletalia alliariae, sozological status, endemic species, Maramureş Mts, Carpathians

\section{Introduction}

Carpathian endemics belong to a relatively well-researched group of plants. Their taxonomy and distribution have been elaborated and refined many times since the 19th century to this day: for smaller parts of the Carpathians (e.g. Kaplan 2012 for the Czech Republic; Kliment 1999 for Slovakia; Piękoś-Mirkowa \& Mirek 2003 and Mirek \& Piękoś-Mirkowa 2009 for the Polish Carpathians; Cornej 2011 and Novikoff \& Hurdu 2015 for the Ukrainian Carpathians; Negrean \& Oltean 1989, Hurdu et al. 2012a and Hurdu et al. 2012b for the Romanian Carpathians); and over the whole mountain range [73, 70, 72, 84, 91, 92, 38]. Many have received attention from the molecular-morphological point of view (e.g. Hodálová 1999 on Senecio nemorensis agg., Těšitel et al. 2009 on Melampyrum saxosum, Kolarčik et al. 2010 on Onosma viridis, Olšavská et al. 2011 on Cyanus triumfetti agg., Şuteu 2012 on several endemic plants in the Eastern and Southern Carpathians, Catană et al. 2013 on Draba dorneri, Kučera et al. 2013 on Cyclamen purpurascens subsp. immaculatum, Kuzmanović et al. 2013 on Sesleria rigida, Şuteu et al. 2013 on Primula leucophylla, Budzáková et al. 2014 on Sesleria tatrae, Bãcilã et al. 2015 on Onobrychis transsilvanica, Ferreira et al. 2015 on Andryala laevitomentosa, Lendvay et al. 2016 on Syringa josikaea, Tkach et al. 2019 on Saxifraga wahlenbergii), phytogeographical-chorological point of view (Pawłowski 1948 on the endemic species of Chyvchyny Mts, Hendrych 1965 on Daphne arbuscula, Hendrych 1981a on endemic plants in 
the former Czecho-Slovakia, Kochjarová et al. 2005 on Scilla kladnii, Bartók et al. 2014 on Heracleum carpaticum, Hurdu et al. 2016 on the centres of endemism in the South-East Carpathians) and biological-ecological point of view (Pawłowski 1969b on the relationship of endemic species to syntaxa (Erdelská \& Turis 1995 on Daphne arbuscula, Piękoś-Mirkowa et al. 1996 on endemic species in the Tatra Mts, Negrea \& Pricop 2009 on Andryala laevitomentosa, Janišová et al. 2012 on Tephroseris longifolia subsp. moravica, Mráz et al. 2016 on endemic species in the West Carpathians, Mihály \& Komendar 1993 on Crocus banaticus, Şuteu et al. 2003 on Astragalus peterfii, Turis 2009 on Cyclamen fatrense, Bahlej 2010 on Saussurea porcii, Lendvay \& Kalapos 2014 on Ferula sadleriana). In spite of this research, for several species, growing mainly in less botanically studied and less accessible areas, the most recent chorological data are missing (e.g. Erysimum hungaricum, Nigritella carpatica, Primula wulfeniana subsp. baumgarteniana), or they have been completed only recently (e.g. Mátis et al. 2014 on Saussurea porcii, Bartók et al. 2016 on Silene zawadzkii in the Făgăraş Mts).

In our article, we summarise information about the taxonomic position, distribution, selected population, coenological and ecological conditions of Erysimum hungaricum Zapał., which is considered to be a stenoendemic species of Mt. Lostun Mic (1595 m) in the Maramureş Mts in Romania.

\section{Material and Methods}

\section{Taxonomy of Erysimum hungaricum}

The species Erysimum hungaricum Zapał. (Fig. 1) was described by Zapałowicz (1913) on the basis of differences in the colour and shape of the edge of the stem leaves, the appearance of saccate bases of sepals, their size, the shape of the petals, the size, colour and hair of the fruits compared with the earlier described species E. wahlenbergii (Asch. et Engl.) Borbás and larger flowers and fruits compared with E. hieracifolium L. All three species are morphologically similar to E. pieninicum (Zapał.) Pawł., E. marschallianum M. Bieb. (ut E. durum Presl in Pawłovski 1946, Latowski 1975) and E. virgatum Roth (synonymous with E. hieracifolium L. according to Euro+Med). Pawłowski (1946) included these 6 species within the common series Hieraciifolia. In this series, also based on their morphological properties, he included the species E. hungaricum, E. wahlenbergii, E. pieninicum and E. virgatum in the subseries Virgata, while he placed the other two species, E. hieracifolium and E. marschallianum, into subseries Euhieraciifolia. Species in the Virgata subseries originated according to Hendrych (1981b) at the end of the Tertiary or at some stage of the Post-Tertiary by geographical differentiation from the species widespread in the Alps and in the Carpathians, which, according to Michalková (2002), was probably E. hieraciifolium s. 1.

According to some authors, E. hungaricum is a separate species due to its morphological features well differentiated from other species of the Virgata subseries [67, 43]. It is also mentioned in many other works at the species level [45, 66, 68, 69, 70, 72, 37, 91, 92, 38]. However, Latowski (1975), based on the results of the morphological study of fruits and seeds, tends to move towards the reassessment of the taxonomic value of the species belonging to the Virgata subseries to the level of subspecies or even variety. Other authors include it together with E. wahlenbergii or E. pieninicum within the wider-delimited species E. hungaricum Zapal., which is widespread not only in the Carpathians [3], but also in the Austrian Alps [53, 76, 77]. Likely based on the work of these authors, Tasenkevich (2002) describes the Carpathian-Alpine 
area of the species. However, the taxon thus understood should be correctly called Erysimum wahlenbergii (Asch. et Engl.) Borbás according to the priority principle of the Code [97], since this species had been validly described before E. hungaricum Zapał. [37]. The species value of E. hungaricum thus conceived has not been rarely accepted and according to Polatschek (cf. Wittmann et al. 1987) it is necessary to assign it to E. virgatum. The latest carpological and molecular research of the species in the Hieraciifolia series shows that they represent a complex of cryptic species, morphologically poorly differentiated but with significant genetic differences [16].

There are discrepancies in the assessment of E. hungaricum by Romanian authors. While Ciocârlan (2009) considers it a critical taxon, Popescu \& Sanda (1998) make it synonymous with E. wahlenbergii and perceive it as a solely Carpathian species. It can be assumed that Sârbu et al. (2013) understand it in a similar way, as they mention the Western and North-Eastern Carpathians in the distribution.

In our work we follow the evaluation of Erysimum hungaricum in the sense of Kliment et al. (2016).

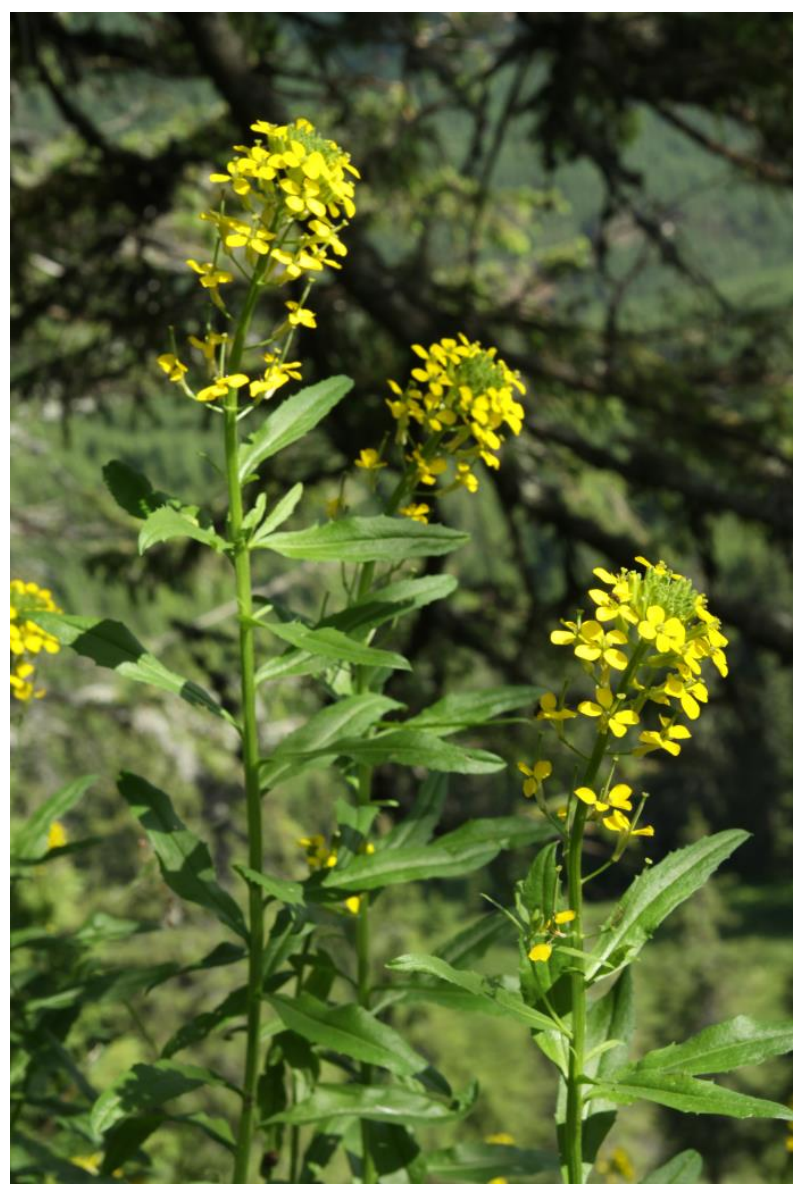

Fig. 1: Flowering plants of Erysimum hungaricum on Mt. Lostun Mic (photo: P. Turis, 12.6.2018)

\section{Sources for the historical distribution of Erysimum hungaricum}

In addition to the published data, we have also used information on the occurrence of the species from the data on the herbarium labels of the only known specimens lodged in the Herbarium of the Polish Academy of Sciences in Cracow (KRAM) and in the Herbarium of the Jagiellonian University in Cracow (KRA). The localities described on the herbarium labels are 
specified in the Results and Discussion chapter in their original wording along with their English translation.

\section{Recent research into Erysimum hungaricum}

The presence of Erysimum hungaricum on Mt. Lostun Mic (1595 m) was verified in June 2018 at the time of flowering. At the site where it occurred, we recorded a phytocoenological relevé using the Zürich-Montpellier school method (Braun-Blanquet 1964) and the extended Braun-Blanquet scale of abundance [4]. Here we took a topsoil sample from four places (no deeper than $15 \mathrm{~cm}$ ), from which a representative soil sample was formed. Carbonate, nitrogen and phosphorus content, also $\mathrm{pH}$ (in $\mathrm{H}_{2} \mathrm{O}$ and $\mathrm{KCl}$ ), were analysed in the laboratory of the National Agriculture and Food Centre, Grassland and Mountain Agriculture Research Institute in Banská Bystrica (Slovakia). Soil characteristics are commented according to Bielek (1998), Gáborík \& Prístavka (2013) and Šimanský et al. (2017).

The plants were determined according to Sârbu et al. (2013) and lodged in the private herbarium of the authors in Banská Bystrica (Slovakia) as documentary material. The nomenclature of vascular plants is according to Popescu \& Sanda (1998) and Euro+Med (2006-), bryophytes according to Hill et al. (2006), and syntaxa according to Sanda et al. (2008). The threat assessment of the species was determined according to the rules defined by IUCN (2012). Toponyms are listed according to the Maramureşului tourist map [50].

\section{Results and Discussion}

\section{Historical distribution of Erysimum hungaricum}

According to literature and herbarium sources, Erysimum hungaricum was studied in the field only by the Polish botanists H. Zapałowicz, at the end of the 19th and the beginning of the 20th century [99], and B. Pawłowski, with his research team in 1933-1936 during the floristicvegetation study of the Chyvchyny Mts [69]. Its presence at this locality had probably not been verified since then. Therefore, only the sites recorded by these two botanists or their collaborators are listed in the historical distribution of the species.

\section{A. Literature sources}

1. Lostun $(1600 \mathrm{~m})$ in latere marmarosiensi in magna rupe calcarea occidentali (a sinistra vallis rivi Lostun, partis fluminis Riu Vaser, sita) 1400-1450 m frequens [99]. - Mt. Lostun Mic $(1600 \mathrm{~m})$ on the Maramureş side on a large limestone rock in the west (left side of the valley of the river Lostun, tributary of the river Rîu Vaser) 1400-1450 m, frequent.

2. Lostun, in rupibus calcareis orientalibus, locis siccioribus 1430-1510 [99]. - Mt. Lostun Mic, on limestone rocks in the east, dry places, 1430-1510 $\mathrm{m}$. The author described E. hungaricum var. subdiscolor Zapał. at this locality.

3. Kocioł Lozduński [69]. - Cirque of Mt. Lostun Mic; detail see in Table 1.

B. Herbarium sources

a) Herbarium KRAM: 5 herbarium specimens in total (some of them including more individuals)

1. Lostun, 16.8.1912, leg. et det. H. Zapałowicz. - Mt. Lostun Mic, 16.8.1912, leg. et det. H. Zapałowicz. This specimen was revised in 1995 by A. Polatschek and marked as the lectotype of E. hungaricum Zapał. 
2. Lostun, 16.8.1912, leg. et det. H. Zapałowicz. - Mt. Lostun Mic, 16.8.1912, leg. et det. H. Zapałowicz. This specimen was revised in 1995 by A. Polatschek and marked as an isotype of E. hungaricum Zapał.

3. Lostun, 16.8.1912, leg. et det. H. Zapałowicz. - Mt. Lostun Mic, 16.8.1912, leg. et det. H. Zapałowicz. This specimen was revised by A. Polatschek [s. a.] and marked as an isotype of E. hungaricum Zapał.

4. Erysimum hungaricum Zap. var. subdiscolor Zap., Lostun, 13.9.1885, leg. et det. H. Zapałowicz. - Erysimum hungaricum Zap. var. subdiscolor Zap., Mt. Lostun Mic, 13.9.1885, leg. et det. H. Zapałowicz. This specimen was revised in 1995 by A. Polatschek as E. hungaricum Zapał.

5. Lostun, 16.8.1912, leg. et det. H. Zapałowicz. - Mt. Lostun Mic, 16.8.1912, leg. et det. H. Zapałowicz.

In this herbarium, there are also several other plants grown in the Botanical Garden of the Jagiellonian University in Cracow from seeds gathered by B. Pawłowski on Mt. Lostun Mic during his research of the Chyvchyny Mts.

b) Herbarium KRA: 9 herbarium specimens in total (some of them including more individuals)

1. Lozdun od poł, skały i upłazy wapienne, $1450-60 \mathrm{~m}, \mathrm{w}$ murawach i na żwirze pod skałami, 20.8.1934, lg. et det. B. Pawłowski. - Mt. Lostun Mic from the south side, limestone rocks and rocky terraces, $1450-60 \mathrm{~m}$, in grasslands and scree under rocks, 20.8.1934, lg. et det. B. Pawłowski.

2. Lozdun od pd., wielka skała wapienna, $1470-90 \mathrm{~m}, 3.6 .1936$, lg. et det. B. Pawłowski. - Mt. Lostun Mic from the south side, large limestone rock, 1470-90 m, 3.6.1936, lg. et det. B. Pawłowski.

3. Lozdun od pd., wielka skała wapienna, 1470-90 m, 3.6.1936, B. Pawłowski. - Mt. Lostun Mic from the south side, large limestone rock, 1470-90 m, 3.6.1936, B. Pawłowski, see Fig. 2.

4. Lostun, jeden z niższych kompleksów skałek po stronie rumuńskiej, 20.8.1934, zb. J. Walas. - Mt. Lostun Mic, one of the lower rock complexes on the Romanian side, 20.8.1934, leg. J. Walas.

5. Lozdun, skały wap., poł. zach., $\pm 1450 \mathrm{~m}$, pod skałami, w murawach i żwirze, 20.8.34, BP. - Mt. Lostun Mic, limestone rocks, southwest, $\pm 1450 \mathrm{~m}$, under rocks, in grasslands and scree, 20.8.1934, B. Pawłowski.

6. Lozdun, wielka skała wapienna w kotle, 1470-90 m, 3.6.1936, lg. et det. B. Pawłowski; Lozdun, 3.6.1936, lg. et det. B. Pawłowski. - Mt. Lostun Mic, large limestone rock in the cirque, 1470-90 m, 3.6.1936, lg. et det. B. Pawłowski; Mt. Lostun Mic, 3.6.1936, lg. et det. B. Pawłowski.

7. Losten, 20.7.1934, lg. et det. J. Walas. - Mt. Lostun Mic, 20.7.1934, lg. et det. J. Walas.

8. Lozd, 20.8.1934, J. Wal. - Mt. Lostun Mic, 20.8.1934, J. Walas.

9. Lozdun, 1450, 20.8.1934, BP. - Mt. Lostun Mic, 1450 m, 20.8.1934, B. Pawłowski. 


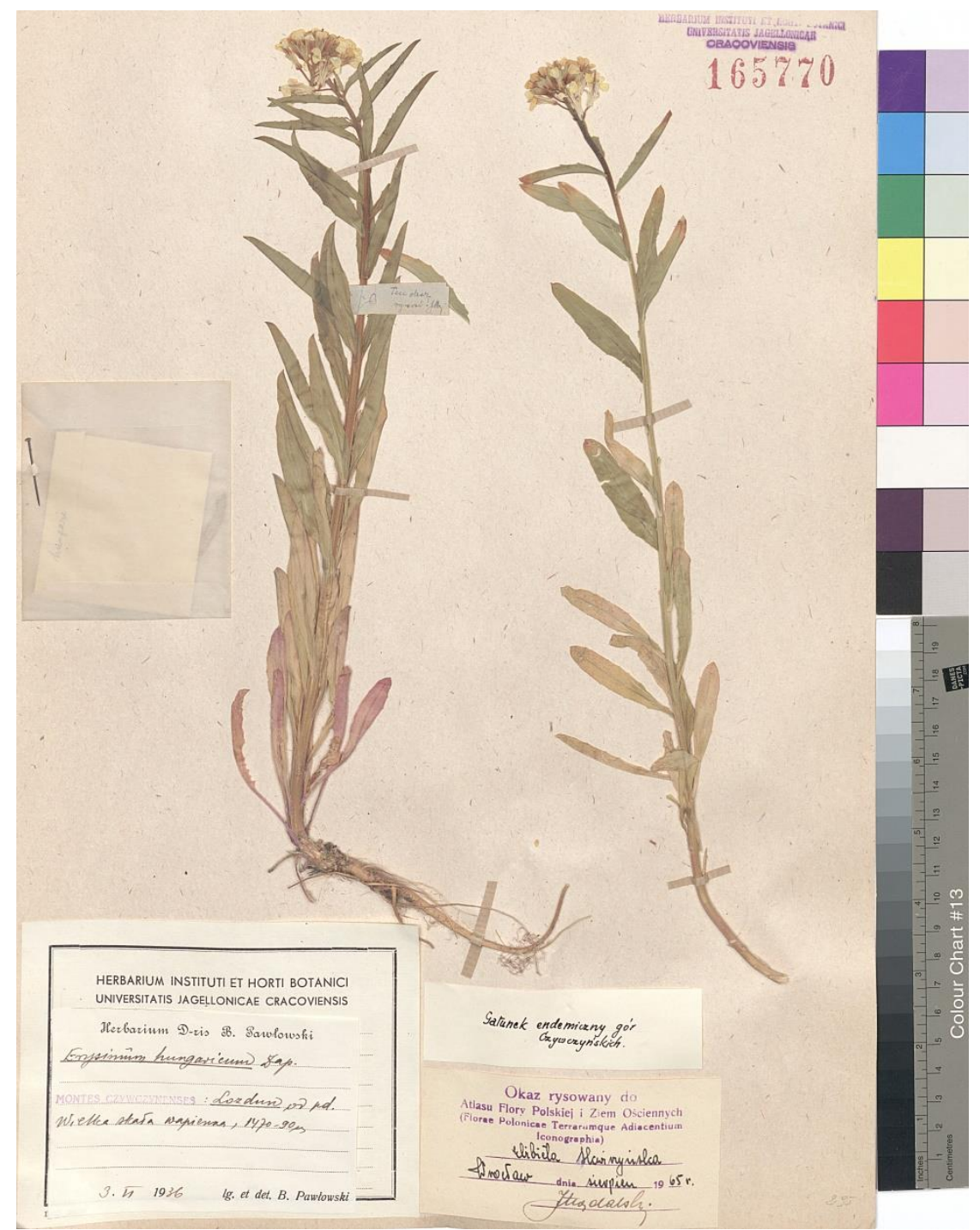

Fig. 2: The scan of the historical specimen of Erysimum hungaricum in Herbarium of the Jagiellonian University in Cracow (Poland)

Based on these records, it can be concluded that in the past E. hungaricum grew in several places on the southern slope of Mt. Lostun Mic (1595 m), situated in the Maramureş Mts. on the Romanian-Ukrainian border. This slope, representing the upper part of the Ştevioara Mare Valley, lies within Romania. Individuals of the wallflower grew on limestone rocks, on the screes below them and in the adjacent dry grasslands of the alliance Festuco saxatilis-Seslerion bielzii (Pawłowski \& Walas 1949) Coldea 1984 [ut Festucion marmarossicae Pawł. et Wal. in Pawłowski \& Walas (1949)] on steep, south to south-west-facing slopes at an altitude of 1400$1510 \mathrm{~m}$ above sea level. Apparently, the largest occurrence was in the area of a large limestone cliff located at 1470-1490 m above sea level on the western side of the valley (see Fig. 3), probably rarer on the eastern side of the valley. The occurrence of the species is reported only in the calciphilous association Festucetum saxatilis Domin 1933 [ut Festucetum saxatilis (Pawł. 1936) Pawł. et Wal. in Pawłowski \& Walas (1949)], which primarily inhabits steep cliffs, but due to the deforestation of the country it also extends to the surrounding areas where it is influenced by livestock grazing [69].

There is inconsistent information about the later presence of the species in the Romanian 
flora. While Săvulescu (1955), Beldie (1977) and Ciocîrlan (1990) do not mention it at all, Oltean et al. (1994) consider it extinct, Oprea (2005) admits its occurrence, and Sârbu et al. (2013) mention the need for its reconfirmation. Only Popescu \& Sanda (1998) do not question its presence. It is rarely mentioned among endangered species of the Ukrainian Carpathians [89, 90], but Prokudin (1987), Kobiv (2007, 2010) and Čornej (2011) correctly report its occurrence only near the Ukrainian-Romanian border on the south side of Mt. Malyj Lostun (= Lostun Mic in Romanian) already in Romania. Data on its occurrence in Slovakia [8, 20, 51, 30] and in Poland [90, 77] relate to the West Carpathian endemic species E. wahlenbergii and E. pieninicum.

\section{Recent occurrence of Erysimum hungaricum}

During our research in 2018, we recorded E. hungaricum only in one place, probably identical to the above-mentioned "large limestone rock" (see Fig. 3). On a very steep slope on the western edge of the rock we found about 100 flowering individuals, with a few others on the rock itself. The vast majority of the population grows in an area of about $20 \times 10 \mathrm{~m}$ under mature Picea abies trees.

The plants were determined on the basis of the length of the sepals (7-8 $\mathrm{mm})$, petals (13$14 \mathrm{~mm}$ ) and anthers (1-2 mm), by which, according to Sârbu et al. (2013), they differ from the similar E. hieracifolium (calyx length 2-6 mm, corona $8.5-12 \mathrm{~mm}$ ) and E. odoratum (anthers length 2-4 mm). At the time of flowering of E. hungaricum, no other species of this genus were seen on the site and none were mentioned by Pawłowski \& Walas (1949).

The historical and recent phytocoenological relevés with the presence of the species (see Table 1) were probably not recorded in the same place, but close to one another. While Pawłowski \& Walas (1949) located its in a typical Festucetum saxatilis association and the presence of E. hungaricum was rather accidental, our relevé was targeted to an area where the species was present. For this reason, the two records cannot be compared for the purpose of assessing possible changes in the community which occurred more than 80 years later.

The place with the actual presence of the species was probably without woody plants in the past, which is confirmed by the still incoherent and uneven growth of trees in the surrounding area. We assume that it was also covered with a Festuca rupicola subsp. saxatilis community, since some of the taxa (e.g. Aconitum anthora, Cirsium erisithales, Erysimum hungaricum, Festuca rupicola subsp. saxatilis, Thymus pulcherrimus) defined by Pawłowski \& Walas (1949) as characteristic of the association Festucetum saxatilis and the alliance Festuco saxatilisSeslerion bielzii are present in our relevé. The cessation of grazing and progressive succession may be the reason for the absence of other characteristic taxa, in particular the light-loving plants of more skeletal and shallower soils (e.g. Jovibarba hirta subsp. glabrescens, Polygala amara subsp. brachyptera, Silene nutans subsp. dubia or Thesium alpinum). At the same time, higher species more demanding of nutrients and soil depth such as Achillea distans, Anthriscus sylvestris, Chaerophyllum hirsutum, Rumex arifolius, Senecio nemorensis, typical of tall-herb vegetation, began to accumulate. The actual community with the presence of E. hungaricum represents the succession stage within the order Adenostyletalia alliariae Br.-Bl. 1931, but its more precise identification is not possible. The steep grassy slope just below the site of our relevé (and beyond the influence of adult Picea abies on vegetation), as well as the slope below the great rock cliff, where, according to the description and species composition, the relevé of 
Pawłowski \& Walas (1949) was most likely recorded, are currently covered with the association Festucetum saxatilis, but without E. hungaricum being present.

Table 1: Phytocoenological relevés with presence of Erysimum hungaricum

(A) historical relevé: cirque Lozduński, altitude $1410 \mathrm{~m}$, area $30 \mathrm{~m}^{2}$, exposition $\mathrm{S}$, slope $30-40^{\circ}$, cover $\mathrm{E}_{\text {total }}$ 85\%, date 20.8.1934 and 3.6.1936 (Pawłowski \& Walas 1949, table II, relevé Nr. 6). Note: Different plant names used by the authors are given in brackets as a synonym.

(B) actual relevé: Mt. Lostun Mic $(1595 \mathrm{~m})$, a steep slope next to a distinctive limestone rock, the stand of higher herbs under an isolated tree group of Picea abies, altitude $1450 \mathrm{~m}$, area $25 \mathrm{~m}^{2}$, exposition S-SE, slope $60^{\circ}$, cover $\mathrm{E}_{\text {total }} 98 \%, \mathrm{E}_{3} 20 \%, \mathrm{E}_{2} 0 \%, \mathrm{E}_{1} 98 \%, \mathrm{E}_{0} 1 \%, 24^{\circ} 47^{\prime} 10.1^{\prime \prime} \mathrm{E}, 47^{\circ} 49^{\prime} 17.6^{\prime \prime} \mathrm{N}( \pm 6 \mathrm{~m})$, date 12.6.2018, authors P. Turis and I. Turisová.

\begin{tabular}{|c|c|c|}
\hline \multirow{2}{*}{ Taxa } & \multicolumn{2}{|c|}{ Abundance } \\
\hline & $\mathbf{A}$ & B \\
\hline $\mathrm{E}_{3}$ & & \\
\hline Picea abies & & $2 b$ \\
\hline 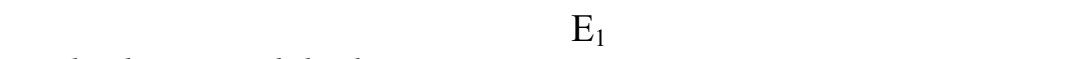 & & \\
\hline Euphorbia amygdaloides & & $2 b$ \\
\hline Luzula sylvatica & & $2 b$ \\
\hline Cirsium erisithales & + & $2 \mathrm{a}$ \\
\hline Erysimum hungaricum & 1 & $2 \mathrm{a}$ \\
\hline Oxalis acetosella & & $2 \mathrm{a}$ \\
\hline Valeriana tripteris & & $2 \mathrm{a}$ \\
\hline Aposeris foetida & & 1 \\
\hline Carduus kerneri (syn. Carduus transsilvanicus) & + & 1 \\
\hline Chaerophyllum hirsutum & & 1 \\
\hline Cystopteris fragilis & + & 1 \\
\hline Fragaria vesca & + & 1 \\
\hline Hieracium murorum & & 1 \\
\hline Picea abies (syn. Picea excelsa) & + & 1 \\
\hline Poa nemoralis & 2 & 1 \\
\hline Rubus idaeus & & 1 \\
\hline Rumex arifolius & & 1 \\
\hline Senecio nemorensis & $\mathrm{r}$ & 1 \\
\hline Taraxacum sp. & & 1 \\
\hline Veronica urticifolia & & 1 \\
\hline Achillea distans (syn. Achillea tanacetifolia) & + & + \\
\hline Aconitum anthora (syn. Aconitum anthora var. Jacquinianum) & + & + \\
\hline Alchemilla sp. & & + \\
\hline Anthriscus sylvestris & & + \\
\hline Arabis alpina & & + \\
\hline Asplenium viride & & + \\
\hline Campanula persicifolia & + & + \\
\hline Cruciata glabra (syn. Galium vernum) & + & + \\
\hline Digitalis grandiflora (syn. Digitalis ambigua) & + & + \\
\hline Epilobium sp. & & + \\
\hline Festuca rupicola subsp. saxatilis (syn. Festuca sulcata var. saxatilis) & 4 & + \\
\hline Galeopsis sp. & & + \\
\hline Glechoma hederacea & & + \\
\hline Hypericum montanum & & + \\
\hline Luzula luzuloides & & + \\
\hline Mycelis muralis & & + \\
\hline Poa chaixii & & + \\
\hline Potentilla aurea & & + \\
\hline Primula elatior & & + \\
\hline Ranunculus nemorosus & & + \\
\hline
\end{tabular}




\begin{tabular}{|c|c|c|}
\hline \multirow{2}{*}{ Taxa } & \multicolumn{2}{|c|}{ Abundance } \\
\hline & $\mathbf{A}$ & B \\
\hline Saxifraga paniculata (syn. Saxifraga aizoon) & + & + \\
\hline Stachys alpina & & + \\
\hline Symphytum tuberosum & & + \\
\hline Thymus pulcherrimus & 1 & + \\
\hline Urtica dioica & & + \\
\hline Veronica chamaedrys & + & + \\
\hline Campanula glomerata & & $\mathrm{r}$ \\
\hline Lilium martagon & + & $\mathrm{r}$ \\
\hline Senecio papposus & + & $\mathrm{r}$ \\
\hline Sorbus aucuparia & & $\mathrm{r}$ \\
\hline Silene nutans subsp. dubia (syn. Silene dubia) & 2 & \\
\hline Scabiosa lucida & 2 & \\
\hline Agropyron caninum & 1 & \\
\hline Lotus corniculatus & 1 & \\
\hline Arabis hornungiana (syn. Arabis Hornungiana) & + & \\
\hline Asplenium ruta-muraria & + & \\
\hline Avenula pubescens (syn. Avena pubescens var. carpatica) & + & \\
\hline $\begin{array}{l}\text { Cardaminopsis halleri subsp. orientalis (syn. Arabis Halleri subsp. } \\
\text { ovirensis var. transsilvanica) }\end{array}$ & + & \\
\hline Carlina acaulis (syn. Carlina acaulis var. alpina) & + & \\
\hline Dianthus carthusianorum (syn. Dianthus carthusianorum var. carpaticus) & + & \\
\hline Euphrasia picta & + & \\
\hline $\begin{array}{l}\text { Helianthemum nummularium subsp. grandiflorum (syn. Helianthemum } \\
\text { obscurum subsp. grandiflorum) }\end{array}$ & + & \\
\hline Heracleum sphondylium & + & \\
\hline Hieracium bifidum & + & \\
\hline $\begin{array}{l}\text { Jovibarba hirta subsp. glabrescens (syn. Sempervivum soboliferum subsp. } \\
\text { hirtellum) }\end{array}$ & + & \\
\hline Laserpitium latifolium & + & \\
\hline Lathyrus pratensis & + & \\
\hline Linum catharticum & + & \\
\hline Mercurialis perennis & + & \\
\hline Phyteuma orbiculare & + & \\
\hline $\begin{array}{l}\text { Polygala amara subsp. brachyptera (syn. Polygala brachyptera var. } \\
\text { carpatica) }\end{array}$ & + & \\
\hline Ranunculus oreophilus (syn. Ranunculus Hornschuchii) & + & \\
\hline Saxifraga luteoviridis (syn. Saxifraga corymbosa subsp. luteoviridis) & + & \\
\hline Thesium alpinum & + & \\
\hline Trisetum alpestre & + & \\
\hline Verbascum lanatum (syn. Verbascum lanatum subsp. Hinkei) & + & \\
\hline Vicia sepium (syn. Vicia sepium var. montana) & + & \\
\hline Viola declinata & + & \\
\hline Acer pseudoplatanus & $\mathrm{r}$ & \\
\hline $\begin{array}{l}\text { Aconitum moldavicum subsp. hosteanum (syn. Aconitum moldavicum subsp. } \\
\text { Hosteanum) }\end{array}$ & $\mathrm{r}$ & \\
\hline Ajuga reptans & $\mathrm{r}$ & \\
\hline Campanula trachelium & $\mathrm{r}$ & \\
\hline Moehringia trinervia & $\mathrm{r}$ & \\
\hline Poa alpina (syn. Poa alpina subsp. gelida) & $\mathrm{r}$ & \\
\hline Total number of taxa & 53 & 49 \\
\hline $\mathrm{E}_{0}$ & & \\
\hline Brachytheciastrum velutinum & & + \\
\hline
\end{tabular}




\begin{tabular}{|c|c|c|}
\hline \multirow[b]{2}{*}{ Taxa } & \multicolumn{2}{|c|}{ Abundance } \\
\hline & $\mathbf{A}$ & B \\
\hline Fissidens sp. & + & \\
\hline Homomallium incurvatum & & + \\
\hline Hylocomium splendens & & + \\
\hline Isothecium alopecuroides & & + \\
\hline Mnium marginatum & & + \\
\hline Thuidium assimile & & + \\
\hline Thuidium sp. & + & \\
\hline Tortella tortuosa & 1 & + \\
\hline Solorina saccata & + & \\
\hline Total number of taxa & 4 & 7 \\
\hline
\end{tabular}

The presence of E. hungaricum in several types of phytocoenoses indicates that it is not strictly bound to a particular community. Its high fidelity to the Festucetum saxatilis association determined by Pawłowski \& Walas (1949) resulted from a very limited distribution and is not a manifestation of ecological demands of the species. In the wider spectrum of phytocoenoses on stabilised screes with shallow, skeletal, moist and humus-rich soils on limestone substrates, there occurs also the more abundant, closely-related West Carpathian E. wahlenbergii [54].

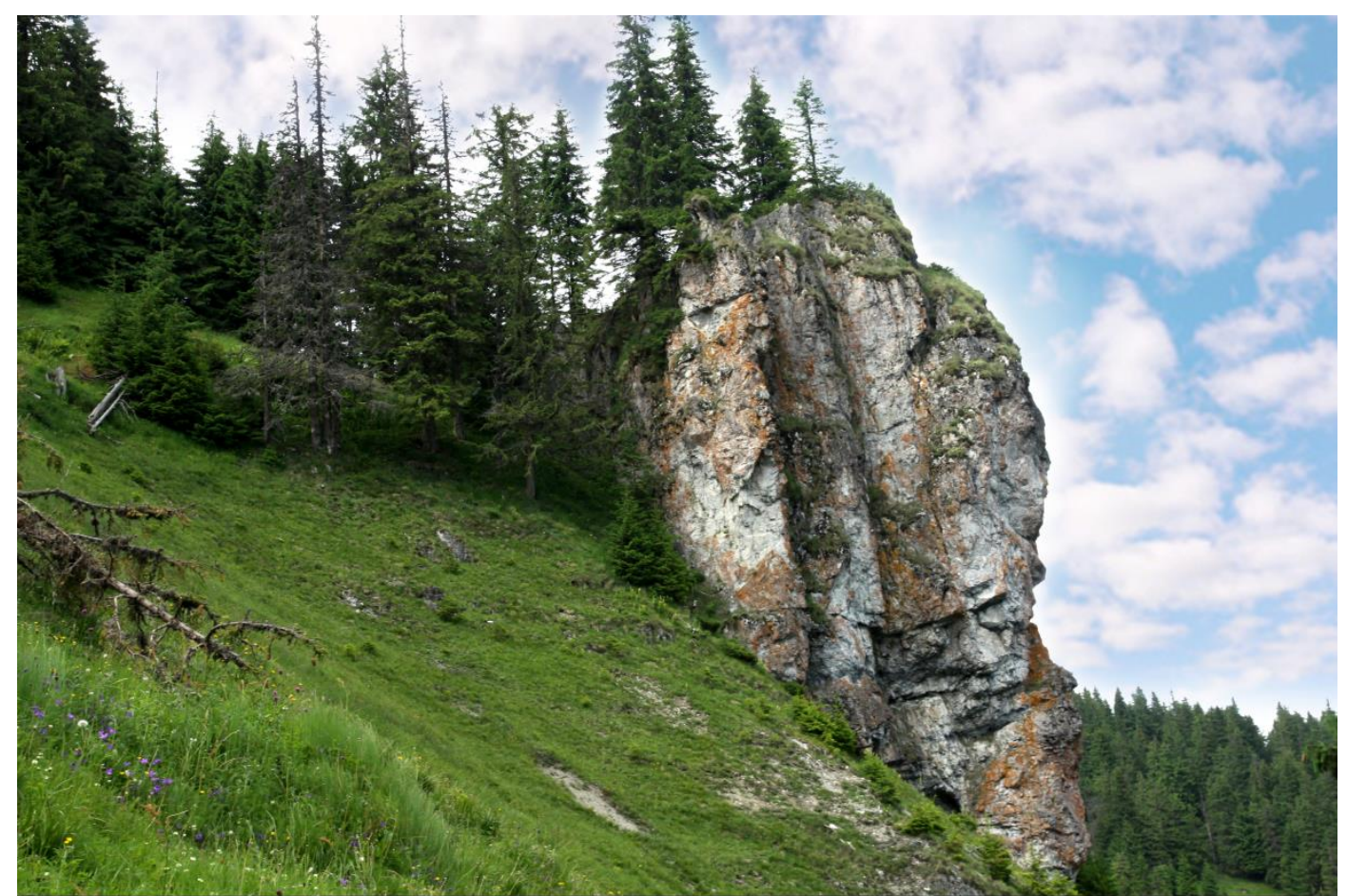

Fig. 3: The locality with recent occurrence of Erysimum hungaricum (photo: P. Turis, 12.6.2018)

\section{Soil properties of localities with Erysimum hungaricum}

Pawłowski \& Walas (1949) consider the association Festucetum saxatilis to be markedly basiphilous and present on calcareous soils. At the site of their phytocoenological relevé with $E$. hungaricum, the soil was strongly calcareous with a neutral reaction. In the current locality, it has a weakly acidic reaction, is very weakly calcareous, and has a very low phosphorus and very high nitrogen content. These values are shown in Table 2. 
Significantly lower levels of carbonate in the soil, as well as slight acidification compared to the past, suggest that E. hungaricum is a more tolerant species capable of growing at different sites. The causes of its extraordinary rarity may lie in the un-investigated biology of the species. Another factor may be the intensive grazing of the meadows, which is uneven on Mt. Lostun Mic, causing their degradation to a nitrified monotonous vegetation of Anthriscus sylvestris or Rumex alpinus.

Table 2: Chemical properties and characteristics of soil with presence of Erysimum hungaricum

\begin{tabular}{|c|c|c|c|}
\hline Chemical properties of soil & A & B & Characteristic (with source) \\
\hline $\mathrm{pH}_{\mathrm{H} 2 \mathrm{O}} / \mathrm{pH}_{\mathrm{KCl}}$ & 7.28 & $6.46 / 6.20$ & neutral (A) / weakly acidic (B) ${ }^{3}$ \\
\hline carbonate content $(\%)$ & 42 & $0.8\left(8.0 \mathrm{~g} \cdot \mathrm{kg}^{-1}\right)$ & $\begin{array}{l}\text { strongly calcareous (A), very weakly } \\
\text { calcareous (B) }{ }^{3}\end{array}$ \\
\hline nitrogen content $\left(\mathrm{g} \cdot \mathrm{kg}^{-1}\right)$ & - & 10.99 & very high (B) ${ }^{1}$ \\
\hline phosphorus content (mg. $\left.\mathrm{kg}^{-1}\right)$ & - & 19.57 & very high $(\mathrm{B})^{2}$ \\
\hline
\end{tabular}

Legend: A - historical relevé (Pawłowski \& Walas 1949), B - actual relevé; index 1 - Bielek 1998, 2 - Gáborík \& Prístavka 2013, 3 - Šimanský et al. 2017

\section{Sozological status of Erysimum hungaricum}

The species is not listed in the Red Book of Vascular Plants of Romania [19] or in other Red Lists of plants of Romania [57, 58, 10, 18] and the Carpathians [96]. The EX (Extinct) sozological status for Romania is mentioned only by Oltean et al. (1994) and Tasenkevich (2002, 2003).

When assessing the threat to the species according to IUCN criteria [34], we have taken into account the current state of the population and the presupposed initial state based on the known information on its distribution. Given the geographic range (AOO $<10 \mathrm{~km}^{2}$ ), actual number of locations $(=1)$, the determined decline of area of occupancy (AOO) and decline number of subpopulations, it belongs to the category of Critically Endangered (CR) according to criteria B2ab(ii,iv).

For these area and population characteristics, the species belongs among the stenoendemics of the Maramureş Mts and the rarest plants of the Carpathians.

Acknowledgment: We would like to thank P. Širka from the Technical University of Zvolen for the determination of bryophytes present in the phytocoenological relevé, A. Stoica and G. Coldea from the Institute of Biological Research Cluj (Romania), and J. Kliment from the Botanical Garden of the Comenius University Blatnica (Slovakia) for their comments on the evaluation of the relevé. We would like to thank B.-M. Brener of the Administration of Maramureşului Mountains Nature Park Vişeu de Sus (Romania) for providing field research assistance. The work was supported by the Scientific Grant Agency (VEGA 2/0040/17).

\section{REFERENCES}

1. Băcilă, I., Şuteu, D., Coldea, G., 2015, Genetic divergence and phylogeography of the alpine plant taxon Onobrychis transsilvanica (Fabaceae), Botany, 93: 257-266.

2. Bahlej, O.V., 2010, Kompleksna ocinka stanu populjacij Saussurea porcii Degen (Asteraceae) v 
Ukraïns'kych Karpatach. In: Roslynnyj svit u Červonyj knyzi Ukraïny: vprovadžennja Hlobal'noï stratehiï zberežennja roslyn, Materialy mižnarodnoï konferenciï (11-15 žovtnja 2010 r., Kyïv), Alterpress, Kyïv: 5557.

3. Ball, P.W., 1993, Erysimum L. In: Tutin, T.G., Burges, N.A., Charter, A.O., Edmondson, J.R., Heywood, V.H., Moore, D.M., Valentine, D.H., Walters, S.M., Webb, D.A. (eds), Flora Europaea, 1. Psilotaceae to Platanaceae, 2. edition. Cambridge University Press: 325-335

4. Barkman, J.J., Doing, H., Segal, S., 1964, Kritische Bemerkungen und Vorschläge zur quantitativen Vegetationsanalyse, Acta botanica Neerlandica, 13: 394-419.

5. Bartók, A., Brener, B.M., Covâză, G., Irimia, I., 2014, Distribution of threatened species Trifolium lupinaster L., Heracleum carpaticum Porcius and Ranunculus thora L. in Romanian Carpathians, Journal of Plant Development, 21: 135-152.

6. Bartók, A., Hurdu, B.I., Szatmari, P.M., Ronikier, M., Puşcaş, M., Novikoff, A., Bartha, L., Vonica, G., 2016, New records for the high-mountain flora of the Făgăraş Mts. (Southern Carpathians) with discussion on ecological preferences and distribution of studied taxa in the Carpathians, Contrib. Bot., 51: 77-153.

7. Beldie, A., 1977, Flora României. Determinator ilustrat al plantelor vasculare. I, Ed. Academiei Republicii Socialiste România.

8. Bernátová, D., 1986, Erysimum hungaricum Zapał. [E. wahlenbergii (Ascherson et Engler) Borbás] vo Vel'kej Fatre, Biologia, 41: 937-938.

9. Bielek, P., 1998, Dusik v polnohospodárskych pôdach Slovenska, Výskumný ústav pôdnej úrodnosti, Bratislava.

10. Boşcaiu, N., Coldea, G., Horeanu, C., 1994, Lista roşie a plantelor vasculare dispărute, periclitate, vulnerabile şi rare din flora României, Ocrotirea Naturii, 38 (1): 45-56.

11. Braun-Blanquet, J., 1964, Pflanzensoziologie, 3, Auflage, Springer-Verlag, Wien.

12. Budzáková, M., Hodálová, I., Mered’a, P. jr., Somlyay, L., Bisbing, S.M., Šibík, J., 2014, Karyological, morphological and ecological differentiation of Sesleria caerulea and S. tatrae in the Western Carpathians and adjacent regions, Preslia, 86: 245-277.

13. Catană, R., Mitoi, M., Ion, R., 2013, The RAPD techniques used to assess the genetic diversity in Draba dorneri, a critically endangered plant species, Advances in Bioscience and Biotechnology, 4: 164-169.

14. Ciocîrlan, V., 199,. Flora Ilustrată a României, II, Determinareă şi descrierea speciilor spontane şi cultivate, Ed. Ceres, Bucureşti.

15. Ciocârlan, V., 2009, Flora Ilustrată a României, Pteridophyta et Spermatophyta, Ed. Ceres, Bucureşti.

16. Czarna, B., Gawrońska, B, Nowińska, R., Morozowska, M., Kosiński, P., 2016, Morphological and molecular variation in selected species of Erysimum (Brassicaceae) from Central Europe and their taxonomic significance, Flora, 222: 68-85.

17. Čornej, I.I., 2011, Krytyčna revizija taksoniv, ščo navodylis' jak endemični dlja flory Ukraïns'kych Karpat, Naukovi Zapiski Bukovins'kogo Tovaristva Prirododoslidnikiv, 1: 23-59.

18. Dihoru, G., Dihoru, A., 1994, Plante rare, periclitate şi endemice in flora Romaniei - Lista roşie, Acta Botanica Horti Bucurestiensis, 1993-1994: 173-197.

19. Dihoru, G., Negrean, G., 2009, Cartea roşie a plantelor vasculare din România, Editura Academiei Române, Bucureşti.

20. Dostál, J., Červenka, M., 1991, Velkký klúč na určovanie vy̌šsich rastlín, I, Slovenské pedagogické nakladatel'stvo, Bratislava.

21. Erdelská, O., Turis, P. (eds), 1995, Biology of Daphne arbuscula Čelak. (Thymelaeaceae), Biologia, 50: 333348.

22. Euro+Med, 2006, Euro+Med PlantBase, The information resource for Euro-Mediterranean plant diversity. http://ww2.bgbm.org/EuroPlusMed/, Accessed 16 February 2019.

23. Ferreira, M.Z., Zahradníček, J., Kadlecová, J., de Sequeira, M.M., Chrtek, J. jr., Fehrer, J., 2015, Tracing the evolutionary history of the little-known Mediterranean-Macaronesian genus Andryala (Asteraceae) by multigene sequencing, Taxon, 64: 535-551 \& Electronic Supplement.

24. Gáborík, Š., Prístavka, M., 2013, Výsledky agrochemického skúšania pôd na Slovensku v rokoch 2006-2011 (XII. cyklus ASP). Ústredný kontrolný a skúšobný ústav pol’nohospodársky, Bratislava.

25. Hendrych, R., 1965, Der Endemismus von Daphne arbuscula Čelak., Acta Universitatis Carolinae, Biol., 1965: 211-226. 
26. Hendrych, R., 1981a, Bemerkungen zum Endemismus in der Flora der Tschechoslowakei, Preslia, 53: 97120.

27. Hendrych, R., 1981b, Rostlinné endemity a jejich zastoupení na území Československa, Živa, 56: 7-9, 45-46, 123-126.

28. Hill, M.O., Bell, N., Bruggeman-Nannenga, M.A., Brugués, M., Cano, M.J., Enroth, J., Flatberg, K.I., Frahm, J.-P., Gallego, M.T., Garilleti, R., Guerra, J., Hedenäs, L., Holyoak, D.T., Hyvönen, J., Ignatov, M.S., Lara, F., Mazimpaka, V., Muñoz, J., Söderström, L., 2006, An annotated checklist of the mosses of Europe and Macaronesia, Journal of Bryology, 28: 198-267.

29. Hodálová, I., 1999, Taxonomy of the Senecio nemorensis group (Compositae) in the Carpathians, Biologia, 54: 395-404.

30. Holub, J., 1999, Erysimum hungaricum Zapał. In: Čeřovský, J., Feráková, V., Holub, J., Maglocký, Š., Procházka, F., Červená kniha ohrozených a vzácnych druhov rastlín a živočíchov SR a ČR. Vol. 5. Vyššie rastliny, Príroda, Bratislava: 152.

31. Hurdu, B.I., Puşcaş, M., Turtureanu, P.D., Niketić, M., Coldea, G., Zimmermann, N.E., 2012a, Patterns of plant endemism in the Romanian Carpathians (South-Eastern Carpathians), Contrib.Bot., 47: 25-38.

32. Hurdu, B.I., Puşcaş, M., Turtureanu, P.D., Niketić, M., Vonica, G., Coldea, G., 2012b, A critical evaluation of the Carpathian endemic plant taxa list from the Romanian Carpathians, Contrib.Bot., 47: 39-47.

33. Hurdu, B.I., Escalante, T., Puşcaş, M., Novikoff, A., Bartha, L., Zimmermann, N.E., 2016, Exploring the different facets of plant endemism in the South-Eastern Carpathians: a manifold approach for the determination of biotic elements, centres and areas of endemism, Biological Journal of the Linnean Society, 119: 649-672.

34. IUCN, 2012, IUCN Red List Categories and Criteria: Version 3.1. Second edition. Gland, Switzerland and Cambridge, UK: IUCN.

35. Janišová, M., Hegedüšová, K., Král', P., Škodová, I, 2012, Ecology and distribution of Tephroseris longifolia subsp. moravica in relation to environmental variation at a micro-scale, Biologia, 67 (1): 97-109.

36. Kaplan, Z., 2012, Flora and phytogeography of the Czech Republic, Preslia, 84: 505-573.

37. Kliment, J., 1999, Komentovaný prehlad vyšších rastlín flóry Slovenska, uvádzaných v literatúre ako endemické taxóny, Bulletin Slovenskej Botanickej Spoločnosti, 21, Suppl. 4: 1-434.

38. Kliment, J, Turis, P., Janišová, M., 2016, Taxa of vascular plants endemic to the Carpathian Mts., Preslia, 88: 19-76.

39. Kobiv, J., Prokopiv, A., Heleš, M., Borsukevyč, L., Nadraha, M., 2007, Pošyrennja i stan populjacij ridkisnych, zahroženych ta endemičnych vydiv roslyn u pivničnij častyni prikordonnoï diljanky Čyvčyns'kych hir (Ukraïns'ki Karpaty), Visnyk L'vivskoho Universytetu, Ser. Biol., 45: 71-84.

40. Kobiv, J., 2010, Ekolohični osoblyvosti oselyšč ridkisnych vydiv roslyn Ukraïns'kich Karpat, Ukrains'kyi Botanicheskii Zhurnal, 67: 355-372.

41. Kochjarová, J., Hrivnák, R., Vlčko, J., 2005, Diploidné populácie Scilla bifolia agg. na Slovensku, Bulletin Slovenskej Botanickej Spoločnosti, 27: 53-62.

42. Kolarčik, V., Zozomová-Lihová, J., Mártonfi, P., 2010, Systematics and evolutionary history of the Asterotricha group of the genus Onosma (Boraginaceae) in central and southern Europe inferred from AFLP and nrDNA ITS data, Plant Systematics and Evolution, 290: 21-45.

43. Konětopský, A., 1963, Nejdůležitější výsledky taxonomické revise československých druhů rodu Erysimum L., Preslia, 35: 135-145.

44. Kučera, J., Turis, P., Zozomová-Lihová, J., Slovák, M., 2013, Cyclamen fatrense, myth or true Western Carpathian endemic? Genetic and morphological evidence, Preslia, 85: 133-158.

45. Kulczyński, S., 1927, Erysimum L., Pszonak. In: Szafer, W. (ed.), Flora Polska. Rośliny naczyniowe Polski i ziem ościennych. III. Polska Akademia Umiejęjtności, Kraków: 163-169.

46. Kuzmanović, N., Comănescu, P., Frajman, B., Lazarević, M., Păun, O., Schönswetter, P., Lakušić, D., 2013, Genetic, cytological and morphological differentiation within the Balkan-Carpathian Sesleria rigida sensu Fl. Eur. (Poaceae): A taxonomically intricate tetraploid-octoploid complex, Taxon, 62: 458-472.

47. Latowski, K., 1975, Badania nad morfologią i anatomią owoców i nasion środkowoeuropejskich gatunków rodzaju Erysimum L., Monografie botaniczne, 49: 5-78.

48. Lendvay, B., Kalapos, T., 2014, Population dynamics of the climate-sensitive endangered perennial Ferula sadleriana Ledeb. (Apiaceae), Plant Species Biology, 29 (2): 138-151. 
49. Lendvay, B., Kadereit, J.W., Westberg, E., Cornejo, C., Pedryc, A., Höhn, M., 2016, Phylogeography of Syringa josikaea (Oleaceae): Early Pleistocene divergence from East Asian relatives and survival in small populations in the Carpathians, Biological Journal of the Linnean Society, 119: 689-703.

50. Maramureşului $1: 65$ 000, Hartă de drumeţie. Hiking map, Munţii Noştri, Editura Schubert \& Franzke SRL, Cluj-Napoca, 2015.

51. Marhold, K., Hindák, F. (eds), 1998, Zoznam nižšich a vyšších rastlín Slovenska, Veda, Bratislava.

52. Mátis, A., Szabó, A., Bartha, L., 2014, Lost and found: rediscovery of Saussurea porcii Degen in the Rodnei mountains (Eastern Carpathians, Romania) after more than a century, Contrib.Bot., 49: 39-42.

53. Melzer, H., Polatschek, A., 1971, Erysimum hungaricum Zapał. - auch in den Ostalpen, Annalen des Naturhistorischen Museums in Wien, 75: 103-109.

54. Michalková, E., 2002, Erysimum L. In: Goliašová, K., Š́́pošová, H., Flóra Slovenska V/4. Veda, Bratislava: $182-226$

55. Mihály, A.V., Komendar, V.I., 1993, State of population of Crocus banaticus J. Gay in the Transcarpathian region of the Tisza valley, Tiscia, 27: 61-63.

56. Mirek, Z., Piękoś-Mirkowa, H., 2009, Fitogeograficzne aspekty endemizmu w Polsce, Wiadomości Botaniczne, 53: 7-30.

57. Moldovan, I., Pázmány, D., Szabó, A., Chircă, E., Leon, Ch., 1984, List of rare, endemic and threatened plants in Romania (I.), Not. Bot. Hort. Agrobot., Cluj-Napoca, 14: 5-16.

58. Moldovan, I., Pázmány, D., Dragoş, L., 1988/89. List of rare, endemic and threatened plants in Romania (II.). Not. Bot. Hort. Agrobot., Cluj-Napoca, 18-19: 67-80.

59. Mráz, P., Barabas, D., Lengyelová, L., Turis, P., Schmotzer, A., Janišová, M., Ronikier, M., 2016, Vascular plant endemism in the Western Carpathians: spatial patterns, environmental correlates and taxon traits, Biological Journal of the Linnean Society, 119: 630-648.

60. Negrea, B.M., Pricop, E., 2009, The endemic plant species Pietrosia levitomentosa, a real conservation challenge, Advances in Environmental Sciences, 1: 1-11.

61. Negrean, G., Oltean, M., 1989, Endemite şi zone endemoconservatoare din Carpaţii Sud-Estici, Ocrotirea Naturii, 33: 15-25.

62. Novikoff, A., Hurdu, B.I., 2015, A critical list of endemic vascular plants in the Ukrainian Carpathians, Contrib.Bot., 50: 43-91.

63. Olšavská, K., Perný, M., Kučera, J., Hodálová, I., 2011, Biosystematic study of the Cyanus triumfetti group in Central Europe, Preslia, 83: 59-98.

64. Oltean, M., Negrean, G., Popescu, A., Roman, N., Dihoru, G., Sanda, V., Mihăilescu, S., 1994, Lista roşie a plantelor superioare din România, Studii, sinteze, documentaţii de ecologie, 1, Academia Română, Institul de Biologie, Bucureşti.

65. Oprea, A., 2005, Lista critică a plantelor vasculare din România, Ed. Universităţii "Alexandru Ioan Cuza", Iaşi.

66. Pawłowska, S., 1953, Rośliny endemiczne w Polsce i ich ochrona, Ochrona przyrody, 21: 1-33.

67. Pawłowski, B., 1946, Pszonaki karpackie, spokrewnione z pszonakiem jastrzębcolistnym. De Erysimis carpaticis, Erysimo hieraciifolio L. Affinibus, Acta Societatis Botanicorum Poloniae, 17: 95-128.

68. Pawłowski, B., 1948, Ogólna charakterystyka geobotaniczna Gór Czywczyńskich, Rozprawy Wydziału Matematyczno-Przyrodniczego Polskiej Akademii Umiejętności, 72B, 6 (1946): 1-75.

69. Pawłowski, B., Walas, J., 1949, Les asociations des plantes vasculaires des Monts de Czywczyn, Bulletin International de l'Académie Polonaise des Sciences et des Lettres, Cl. Math.-Nat., Ser. B (I), 1948: 117-181.

70. Pawłowski, B., 1969a, Die Karpaten und die Sudeten - eine vergleichende pflanzengeographische Studie, Archiv für Naturschutz und Landschaftsforschung, 9: 251-263.

71. Pawłowski, B., 1969b, Der Endemismus in der Flora der Alpen, der Karpaten und der balkanischen Gebirge im Verhältnis zu den Pflanzengesellschaften, Mitteilungen der Ostalpin-Dinarischen Pflanzensoziologischen Arbeitsgemeinschaft, 9:167-178.

72. Pawłowski, B., 1970, Remarques sur l' endémisme dans la flore des Alpes et des Carpates, Vegetatio, 21: 181-243.

73. Pax, F., 1898, Grundzüge der Pflanzenverbreitung in den Karpathen, 1, Wilhelm Engelmann, Leipzig.

74. Piękoś-Mirkowa, H., Mirek, Z., Miechówka, A., 1996, Endemic vascular plants in the Polish Tatra Mts. distribution and ecology, Polish Botanical Studies, 12: 1-107. 
75. Piękoś-Mirkowa, H., Mirek, Z., 2003, Endemic taxa of vascular plants in the Polish Carpathians, Acta Societatis Botanicorum Poloniae, 72: 235-242.

76. Polatschek, A., 2010, Revision der Gattung Erysimum (Cruciferae): Teil 1: Russland, die Nachfolgestaaten der USSR (excl. Georgien, Armenien, Azerbaidzan), China, Indien, Pakistan, Japan und Korea, Annalen des Naturhistorischen Museums in Wien, B, 111: 181-275.

77. Polatschek, A., 2013, Revision der Gattung Erysimum (Cruciferae): Teil 5: Nord-, West- Zentraleuropa Rumänien und westliche Balkan-Halbinsel bis Albanien, Annalen des Naturhistorischen Museums in Wien, $B$, 115: 75-218.

78. Popescu, A., Sanda, V., 1998,. Conspectul florei cormofitelor spontane din România, Acta Botanica Horti Bucurestiensis, Editura Universităţii din Bucureşti.

79. Prokudin, J.N. (ed.), 1987, Opredelitel'vysšich rastenij Ukraïny, Naukova dumka, Kï̈v.

80. Sanda, V., Öllerer, K., Burescu, P., 2008, Fitocenozele din România. Sintaxonomie, structură, dinamică şi evoluţie, Ed. Ars Docendi, București.

81. Sârbu, I., Ştefan, N., Oprea, A., 2013, Plante vasculare din România. Determinator ilustrat de teren, Victor B Victor, București.

82. Săvulescu, T. (ed.), 1955, Flora Republicae Popularis Romanicae III, Ed. Academia Republicae Popularis Romanicae.

83. Šimanský, V., Polláková, N., Chlpík, J., Kolenčík, M., 2017, Návody na cvičenia z pôdoznalectva, SPU v Nitre, Nitra.

84. Soó, R., 1933, Analyse der Flora des historischen Ungarns. (Elemente, Endemismen, Relikte.), A Magyar Biologiai Kutatóintézet Munkái, 6: 173-194.

85. Şuteu, A., Gafta, G., Groza, G., 2003, Reproductive and distribution patterns in two populations of the rare endemic Astragalus peterfii Jáv. (Transylvania, Romania), Bocconea, 16: 455-464.

86. Şuteu, D., Puşcaş, M, Băcilă, I., Coste, A., Filipaş, L., Stoica, I.A., Hurdu, B.I., Ursu, T., Coldea, G., 2011, Does Primula intricata Gren. et Godr. merit species rank? A taxonomic revision based on nrDNA, cpDNA and AFLP data, Notulae Botanicae Horti Agrobotanici Cluj-Napoca, 39 (1): 24-29.

87. Şuteu, D.C., 2012, Molecular taxonomy studies on several endemic and rare plants species from Romania, Summary of the $\mathrm{PhD}$ thesis, Babeş-Bolyai University, Cluj-Napoca.

88. Şuteu, D., Puşcaş, M., Filipaş, L., Băcilă, I., Hurdu, B.I., Coldea, G., 2013, Primula leucophylla in SouthEastern Carpathians: a genetic and morphometric study within Primula elatior group, Acta biologica Cracoviensia, Bot., 55, Suppl. 1: 69.

89. Tasenkevich, L., 2002, Red list of vascular plants of the Carpathian mountains, State museum of natural history NAS of Ukraine, Lviv.

90. Tasenkevich, L., 2003, Vascular plants. In: Witkowski, Z.J., Król, W., Solarz W. (eds), Carpathian List of Endangered Species, WWF and Institute of Nature Conservation, Polish Academy of Sciences, ViennaKrakow: 6-19.

91. Tasenkevich, L., 2011, Endemism in the Carpathian flora - a chorological aspect. In: Zemanek, B. (ed.), Geobotanist and taxonomist. A volume dedicated to Professor Adam Zajac on the 70th aniversary of his birth, Institute of Botany Jagellonian University, Cracow: 157-168.

92. Tasenkevyč, L., 2014, Endemizm flory Karpat - ekolohični ta chorolohični osoblyvosti, Pratsi naukovogo tovarystva im. Shevchenka, 39: 22-36.

93. Těšitel, J., Malinová, T., Štech, M., Herbstová, M., 2009, Variation in the Melampyrum sylvaticum group in the Carpathian and Hercynian region: two lineages with different evolutionary histories, Preslia, 81: 1-22.

94. Tkach, N., Röser, M., Suchan, T., Cieślak, E., Schönswetter, P., Ronikier, M., 2019, Contrasting evolutionary origins of two mountain endemics: Saxifraga wahlenbergii (Western Carpathians) and S. styriaca (Eastern Alps), BMC Evolutionary Biology, 19:18.

95. Turis, P., 2009, Ekobiológia, vybrané populačné charakteristiky, rozšírenie a ochrana cyklámenu fatranského vo východnej časti areálu, PhD thesis, Institute of Landscape Ecology, Slovak Academy of Sciences, Bratislava.

96. Turis, P., Eliáš, P. jun., Schmotzer, A., Király, G., Schneider, E., Kuciel, H., Szewczyk, M., Kozurak, A., Antosyak, A., Voloshchuk, M., Lazarević, P., Lustyk, P., 2014, Red List of vascular plants of the Carpathians. In: Kadlečík, J. (ed.), Carpathian Red List of forest habitats and species. Carpathian list of invasive alien species, (Draft), The State Nature Conservancy of the Slovak Republic: 44-105. 
97. Turland, N.J., Wiersema, J.H., Barrie, F.R., Greuter, W., Hawksworth, D.L., Herendeen, P.S., Knapp, S., Kusber, W.-H., Li, D.-Z., Marhold, K., May, T.W., McNeill, J., Monro, A.M., Prado, J., Price, M.J., Smith, G.F. (eds.), 2018, International Code of Nomenclature for algae, fungi, and plants (Shenzhen Code) adopted by the Nineteenth International Botanical Congress Shenzhen, China, July 2017. Regnum Vegetabile 159. Glashütten: Koeltz Botanical Books.

98. Wittmann, H., Siebenbrunner, A., Pilsl, P., Heiselmayer, P., 1987, Verbreitungsatlas der Salzburger Gefäszpflanzen, Abakus Verlag, Salzburg.

99. Zapałowicz, H., 1913, Conspectus florae Galiciae criticus. Krytyczny przegląd roślinności Galicyi. XXVII, Rozprawy Wydziatu Matematyczno-Przyroniczy Akademii Umiejejtności, Ser. 3B, 13: 29-49.

\section{MAI EXISTĂ ERYSIMUM HUNGARICUM ZAPAŁ. (BRASSICACEAE) ÎN ROMÂNIA?}

\section{(Rezumat)}

Specia carpatică stenoendemică Erysimum hungaricum Zapał. (Brassicaceae) nu a mai fost observată de mai bine de 80 de ani în singura localitate ştiută din Munţii Maramureşului, România. Cercetările din iunie 2018 au confirmat prezenţa speciei pe partea sudică a Muntelui Lostun Mic (1595 m). Numărul microstaţiunilor s-a redus la una singura, de circa $200 \mathrm{~m}^{2}$. În populaţia rămasă, de aproximativ 100 indivizi în floare, s-a făcut un releveu fitosociologic şi s-au determinat proprietatile chimice ale solului $\left(\mathrm{pH}_{\mathrm{H} 2 \mathrm{O}}=6.46 ; \mathrm{pH}_{\mathrm{KCl}}=6.2\right.$; conţinutul de carbonat $=8.0$ g. $\mathrm{kg}^{-1}$; conţinutul de azot $=10.99 \mathrm{~g} \cdot \mathrm{kg}^{-1}$; conţinutul de fosfor $=19.57 \mathrm{mg} \cdot \mathrm{kg}^{-1}$ ). În comunitatea vegetală, succesiunea a început de la Festucetum saxatilis Domin 1933 la o vegetaţie de ierburi înalte din ordinal Adenostyletalia alliariae Br.-Bl. 1931 până la Picea abies. Prezenţa speciei în diferitele unităţi de vegetaţie şi compararea caracteristicilor actuale ale solului cu cele mai vechi au indicat o toleranţă mai mare a speciei la caracteristicile sitului. Astfel, motivele pentru care această specie este deosebit de rară nu sunt deplin înţelese. Pe baza evaluării sozologice IUCN, specia a fost catalogată ca fiind critic periclitată (CR), conform criteriului B2ab(ii, iv). 